\title{
PERENCANAAN PENGEMBANGAN KAWASAN KOPI DI KABUPATEN REJANG LEBONG, PROVINSI JAMBI
}

\author{
Fery Murtiningrum ${ }^{1}$, Hefri Oktoyoki ${ }^{1}$. \\ 1Program Studi Agribisnis Universitas Pat Petulai \\ Email: ferymurtiningrum@yahoo.co.id
}

\begin{abstract}
Planning is important in carrying out an activity or activity, especially development activities. Planning is an effort in selecting and linking facts and making and using assumptions about the future by describing and formulating the activities needed to achieve the desired outcome (Susanto, 2016). Rejang Lebong Regency is one of the Regencies in Bengkulu Province that is included in the zone for the development of the Coffee Agribusiness area. Planning for the development of the coffee area was arranged by the Bengkulu Provincial Government. This study aims to examine the concepts related to coffee area development planning. The research method used is based on a literature review. From the results of the Literature study it was found that planning for the development of the coffee area in Rejang Lebong Regency should be carried out in accordance with considering the condition of the land, weather and climate of the region in Rejang Lebong Regency.
\end{abstract}

Keywords: Planning, Regency, Coffea, Development

\begin{abstract}
Abstrak. Perencanaan adalah hal yang penting dalam melakukan suatu kegiatan atau aktvitas , terutama aktivitas pembangunan. Perencanaan adalah suatu upaya dalam memilih dan menghubungkan fakta- fakta dan membuat serta menggunakan asumsi - asumsi mengenai masa yang akan datang dengan jalan menggambarkan dan merumuskan kegiatan - kegiatan yang diperlukan untuk mencapai hasil yang dinginkan (Susanto, 2016). Kabupaten Rejang Lebong adalah salah satu Kabupaten di Provinsi Bengkulu yang masuk di dalam zona untuk pengembangan kawasan agribisnis Kopi. Perencanaan untuk pengembangan kawasan kopi di susun oleh Pemerintah Provinsi Bengkulu. Penelitian ini bertujuan untuk mengkaji konsep yang berkaitan dengan perencanaan pengembangan kawasan kopi. Metode penelitian yang digunakan berdasarkan kajian literature. Dari Hasil studi Literatur di dapatkan bahwa perencanaan pengembangan kawasan kopi di Kabupaten Rejang Lebong sebaiknya dilakukan sesuai dengan mempertimbangkan kondiri lahan, cuaca dan iklim kawasan di Kabupaten Rejang Lebong.agar dapat menghasilkan produksi yang optimal.
\end{abstract}

Kata kunci: Perencanaan, Wilayah, Kopi, Pembangunan

\section{PENDAHULUAN}

Teori menyebutkan bahwa salah satu cara yang efektif dalam membangun wilayah adalah melalui pengembangan kawasan, lebih khusus lagi melalui pendekatan klaster. Dalam suatu klaster, berbagai kegiatan ekonomi dari para pelaku usaha saling berinteraksi dan mendukung satu sama lain menghasilkan barang dan jasa yang unik. Bagaimana mengembangkan kegiatan usaha yang saling mendukung itu merupakan kunci bagi pengembangan ekonomi suatu wilayah. Pembangunan wilayah bukanlah semata mata fenomena dalam dimensi lokal dan regional tetapi merupakan bagian yang tak terpisahkan dari pembangunan makro (Skala nasional) bahkan global. Secara historis kegagalan program program pembangunan di dalam mencapai tujuanya seringkali bukan semata mata kegagalan di dalam program atau pelaksanaan pembangunan itu sendiri tetapi ada sumbangan kesalahan karena berkembangnya kepercayaan terhadap kebenaran teori teori atau konsep konsep pembangunan yang melandasinya (Ernan Rustiadi. Sunsun Saefulhakim. Dyan R, 2009)

Perencanaan adalah suatu upaya dalam memilih dan menghubungkan fakta fakta dan membuat serta menggunakan asumsi asumsi mengenai masa yang akan datang dengan jalan menggambarkan dan merumuskan kegiatan kegiatan yang diperlukan untuk mencapai hasil yang dinginkan (Susanto, 2016) Menurut Kunarjo (2002) dalam (Syafa'at, et al 2016), Perencanaan dapat disusun berdasarkan beberapa kriteria, antara lain menurut jangka waktu, menurut ruang lingkup atau tingkat keluwesan. Menurut jangka waktu, ada rencana jangka panjang, jangka menengah dan jangka pendek. Perencanaan jangka panjang menurut Tjokroamidjojo (1994) mempunyai sifat dua macam: pertama, merupakan proyeksi keadaan masa depan dengan jangka waktu yang cukup panjang, kedua perencanaan kebijaksanaan yang dimaksudkan untuk mencapai tujuan tujuan perkembangan dalam masyarakat yang bersifat fundamental dan struktural. Sementara itu menurut (Kunarjo, 2002) perencanaan 
biasanya dikaitkan dengan kebutuhan politis seseorang berdasarkan jangka waktu jabatan para pengusaha. Dan perencanaan jangka pendek dapat juga di katakan sebagai perencanaan operasional tahunan yang mempunyai kurun waktu yang pendek yaitu hanya satu tahun.

Pembangunan adalah suatu proses menuju keadaan yang lebih baik bagi masyarakat atau sistim sosial yang dilakukan secara berkelanjutan. Menurut (Todaro, 2000) pembangunan harus memiliki tiga komponen dasar yang dijadikan sebagai basis konseptual dan pedoman praktis dalam memahami pembangunan yang paling hakiki, yaitu kecukupan (sustainance) memenuhi kebutuhan pokok, meningkatkan rasa harga diri atau jati diri (self-esteem), serta kebebasan (freedom) untuk memilih. Todaro berpendapat bahwa pembangunan harus di pandang sebagai suatu proses multidimensional mencakup berbagai perubahan mendasar atas struktur sosial, sikap sikap masyarakat, dan institusi institusi nasional disamping tetap mengejar akselerasi pertumbuhan ekonomi, penanganan ketimpangan pendapatan, serta pengentasan kemiskinan.

Tujuan Akhir pembangunan nasional adalah mewujudkan keadilan sosial bagi seluruh rakyat Indonesia yang merupakan pengamalan dari sila terakhir dari pancasila. Pembangunan pertanian adalah kegiatan pembangunan untuk meningkatkan produksi disemua sektor pertanian

Dalam bidang Pertanian, menurut (Sri Sudalmi, 2010) Pembangunan pertanian bertolak dari empat dimensi sudut pandang yaitu:

- Usaha sebagai tuntutan operasional dari curahan karya manusia dalam memanfaatkan kekayaan alam ( lahan, air, iklim, biota, sinar/ cahaya) untuk pemenuhan kebutuhan dan kesejahteraan hidup.

- Wilayah sebagai sistem pemberdayaan masyarakat yang menjadi wadah panduan interaksi atau pelaku dan keterkaitan intersektoral secara tertib dan terkendali.

- Agribisnis sebagai sistem integrasi fungsional secara vertikal untuk merespons tuntutan industrialisasi dan persaingan terbuka.

- Lingkungan sebagai wujud dari asas keseimbangan alami yang menjadi kekuatan daya dukung alam bagi keberlangsungan dan kelestarian kehidupan manusia, yang cenderung lupa diri karena obsesi meraih kepuasan yang tanpa batas.

Teori menyebutkan bahwa salah satu cara yang efektif membangun wilayah adalah dengan pengembangan kawasan (BAPPENAS, 2004) Kawasan adalah suatu wilayah atau daerah tertentu yang mempunyai fungsi tertentu. Kawasan adalah wilayah yang berbasis pada keberagaman fisik dan ekonomi tetapi memiliki hubungan erat dan saling mendukung satu sama lain secara fungsional demi mempercepat pertumbuhan ekonomi daerah dan meningkatkan kesejahteraan rakyat. Dalam kaitan ini, kawasan didefinisikan sebagai kawasan yang mempunyai fungsi tertentu, dimana kegiatan ekonominya, sektor dan produk unggulannya, mempunyai potensi mendorong pertumbuhan ekonomi wilayah sekitarnya. Kawasan ini secara sendiri-sendiri maupun secara bersama membentuk suatu klaster. Klaster dapat berupa klaster pertanian dan Secara sederhana perencanaan adalah menetapkan suatu tujuan dan memilih langkah langkah yang diperlukan untuk mencapai tujuan tersebut (Tarigan, 2016).

Pendekatan pengembangan kawasan pertanian yang dimaksud untuk meningkatkan produksi, produktivitas, daya saing komoditas unggulan nasional, efektivitas kegiatan, efisiensi anggaran dan mendorong keberlanjutan kawasan komoditas unggulan. Dengan arah pengembangan kawasan yaitu fokus komoditas, keterpaduan kegiatan, lokasi kegiatan, pembiayaan antara pemerintah pusat, pemerintah daerah dan swasta. Penerapan Pengembangan Kawasan Pertanian diharapkan mampu meningkatkan daya saing Komoditas Unggulan berbasis potensi sumber daya kawasan.

Konsep dan pendekatan pengembangan kawasan pertanian, strategi, dan kebijakan pendukungnya serta langkah langkah implementasinya telah dituangkan didalam peraturan Menteri Pertanian Nomor 50 Tahun 2012 tentang Pedoman Pengembangan Kawasan Pertanian. Strategi umum dan Langkah Langkah Pengembangan Kawasan Pertanian diatur dalam Permentan 50/2012 dan Rencana Strategis Kementrian Pertanian 20152019 yaitu sebagai berikut: (1).Penguatan Perencanaan; (2) Penguatan Kerjasama dan Kemitraan; (3) Penguatan Sarana dan Prasarana; (4) Penguatan Sumber Daya Manusia; (5) Penguatan Kelembagaan; dan (6) Percepatan Adopsi Teknologi Bioindustri dan 
Bioenergi, dan (7) Pengembangan Industri Hilir.

Arah kebijakan dan strategi pembangunan pertanian dengan pendekatan pengembangan kawasan pertanian dimaksudkan untuk menjamin ketahanan pangan nasional, pengembangan dan penyedian bahan baku agroindustri, serta penyediaan bahan bakar nabati. Disamping itu, pengembangan kawasan pertanian juga dimaksudkan untuk mendukung pengembangan kawasan perbatasan daerah tertinggal serta mendukung keterkaitan pembangunan antara desa dan kota.

\section{METODE}

\section{Lokasi dan Ruang Lingkup Penelitian \\ 1.1 Lokasi Penelitian}

Penelitian di lakukan di Wilayah Kabupaten Rejang Lebong Provinsi Bengkulu dengan alasan Wilayah Kabupaten Rejang Lebong merupakan wilayah yang menjadi lokasi dari Perencanaan Master Plan Agrowisata Kampung Kopi.

\subsection{Ruang Lingkup Penelitian}

Penelitian dilakukan terhadap proses perencanaan pengembangan kawasan pertanian di tingkat Kabupaten Rejang Lebong.

\subsection{Jenis Penelitian}

Penelitian ini berdasarkan review literatur penelitian ilmiah yang telah di publikasi di dalam jurnal penelitian, buku, laporan nasional, regional dan organisasi internasional, Disertasi, , prosiding seminar dan lainnya

\subsection{Jenis dan Sumber Data}

Data yang digunakan adalah data sekunder berdasarkan hasil review literatur hasil penelitian ilmiah yang telah dipublikasikan di dalam jurnal penelitian, buku, laporan nasional, regional dan organisasi internasional, tesis, prosiding seminar dan lainnya

1.5 Teknik Pengumpulan Data

Dokumentasi yaitu melakukan pengamatan/penelitian terhadap berbagai dokument hasil publikasi penelitian penelitian sebelumnya, dari jurnal, buku buku, tesis, prosiding seminar dan lainnya.

\section{HASIL DAN PEMBAHASAN}

Pembangunan kawasan adalah usaha untuk mengembangkan dan meningkatkan hubungan saling tergantungan dan interaksi atara sistem ekonomi (economic system), masyarakat (social system), dan lingkungan hidup beserta sumberdaya alamnya (ecosystem). Setiap sistem ini memiliki tujuannya masing masing.

Pengembangan suatu kawasan adalah suatu bentuk kerja bersama dari berbagai sektor terkait pemangku kepentingan dimana diawali dengan optimalisasi potensi komoditas unggulan yang telah ada dan berkembang pada suatu wilayah dan kemudian secara terarah dan terfokus dikembangkan dengan melihat dan memperhatikan keterikatan dan keterkaitan hulu hilir sebagai suatu kesatuan. Kontribusi dari berbagai sektor terkait pengembangan kawasan antara lain adalah sektor perindustrian, perdagangan, koperasi, dan usaha kecil dan menengah, Pekerjaan umum, pusat penelitian, perguruan tinggi, swasata, asosiasi, perbankan, dan berbagai pemangku kepentingan lainnya.

Pengembangan kawasan tergantung bagaimana karakteristik kawasan, apakah merupakan kawasan yang sudah berkembang/maju, kawasan cukup berkembang atau kawasan belum berkembang. Kategori kawasan dilihat berdasarkan ketersediaan subsistim agribisnis didalam kawasan, kemandirian pelakunya, serta kuantitas dan kualitas produk yang dihasilkan, Apabila subsistim agribisnis yang ada sudah berjalan dengan efektif, para pelakunya mandiri, dan produk yang dihasilkan sudah berkualitas dan berkelanjutan, maka kawasan tersebut dapat dikategorikan sebagai kawasan sudah berkembang/maju atau sebaliknya.

Langkah langkah pengembangan Kawasan yang dilakukan oleh Pemerintah Kabupaten Rejang Lebong meliputi:

\section{Penguatan Perencanaan}

Perencanaan pengembangan kawasan komoditas unggulan dilakukan melalui pendekatan top-down policy yaitu sejalan dengan arah kebijakan pembangunan pertanian nasional, dan bottom-up planning, sesuai dengan kebutuhan masyarakat/petani.

Proses perencanaan pengembangan kawasan melibatkan keterpaduan 
program antar eselon I lingkup Kementrian Pertanian dan Lintas Sektor. Meskipun demikian perencanaan pengembangan kawasan harus memperhatikan isu - isu strategis yang berkembang di daerah. Program program yang akan dilaksanakan harus sesuai dengan kebutuhan pengembangan kawasan dan mampu menumbuhkan sikap partisipatif sasaran. Keluaran dari perencanaan adalah rancang bangun kawasan dan rencana aksi baik dalam jangka menengah maupun jangka panjang dalam rincian tahunan.

Penguatan perencanaan ini tentunya didukung pula oleh adanya sumber daya yang ada di Kabupaten Rejang Lebong yaitu berupa luasan lahan yang memungkinkan untuk diolah menjadi lahan pertanian baik dalam bentuk perluasan lahan maupun diversifikasi tanaman. Berdasarkan data RSPS Lahan Tahun 2017, sumber daya lahan di Kabupaten Rejang Lebong dapat dilihat pada Tabel 1 berikut:

Tabel 1. Sumber daya lahan di Kabupaten Rejang Lebong Tahun 2017.

\begin{tabular}{|c|c|c|c|}
\hline \multirow{2}{*}{ No } & \multirow{2}{*}{ Jenis Penggunaan Lahn } & \multicolumn{2}{|c|}{ Luas } \\
\hline & & Luas $(\mathrm{Ha})$ & $(\%)$ \\
\hline \multirow[t]{5}{*}{1} & Lahan Sawah & $9,952.0$ & 6,57 \\
\hline & a. Irigasi & $8,684.0$ & 88,53 \\
\hline & b. Tadah Hujan & 647,0 & 6,60 \\
\hline & c. Rawa Pasang Surut & - & \\
\hline & d. Rawa Lembak & 621,0 & 6,33 \\
\hline \multirow[t]{10}{*}{2} & Lahan bukan sawah & $131,814.5$ & 86.96 \\
\hline & a. Tegal/Kebun & $44,219.0$ & 29.17 \\
\hline & b. Ladang/huma & $15,173.0$ & 10.17 \\
\hline & c. Perkebunan & $30,517.0$ & 20.13 \\
\hline & d. Ditanami pohon/Hutan Rakyat & $8,457.0$ & 5.58 \\
\hline & e. Tambak & . & \\
\hline & f. Kolam/Tebat/Empang & - & \\
\hline & g. Padang pengembalaan/Rumput & 8.0 & 0.01 \\
\hline & h. Sementara tidak diusahakan & $3,725.5$ & 2.46 \\
\hline & $\begin{array}{lll}\text { i. } & \begin{array}{l}\text { Lainnya } \\
\text { ditanami) }\end{array} & \text { (Pekarangang } \\
\end{array}$ & $29,715.0$ & 19.60 \\
\hline 3 & $\begin{array}{l}\text { Lahan Bukan pertanian } \\
\text { a. Rumah, Bangunan dan Halaman } \\
\text { b. Hutan Negara } \\
\text { c. Rawa-Rawa (tidak ditanami) } \\
\text { d. Lainnya (jalan, sungai, danau, } \\
\text { lahan) }\end{array}$ & $9,809.0$ & 24,87 \\
\hline
\end{tabular}

Sumber : Data RPSP_Lahan Dinas Pertanian Kabupaten Rejang Lebong Tahun 2018

\section{Penguatan Kerjasama dan Kemitraan}

Keterbatasan dan ketimpangan baik dalam potensi maupun sumber daya yang dimiliki oleh Pemerintah Daerah, merupakan salah satu faktor yang akan mempengaruhi pengembangan kawasan pertanian. Untuk itu diperlukan kerjasama kemitraan startegis baik antar daerah, badan usaha daerah, maupun swasta dan masyarakat. Kerjasama kemitraan strategis model klaster, harus mampu memberikan layanan kepada kelompok usaha lebih fokus, kolektif dan efisien. Karena kelompok sasaran jelas serta unit usaha yang ada pada kawasan pada umumnya mempunyai permasalahan yang sama, baik dari sisi produksi, pemasaran, teknologi maupun permodalan. 


\section{Penguatan Sarana dan Prasarana}

Aspek dasar pengembangan kawasan terdiri dari pengembangan sarana dan prasarana produksi, lahan, air, pertanian serta prasarana pendukung. Penguatan sarana prasarana produksi pertanian seperti benih/bibit, pupuk dan obat obatan harus dijamin ketersediannya, baik dalam jumlah dan ketepatan waktu. Berkaitan dengan sumberdaya lahan dan air, aspek yang perlu mendapatakan perhatian yaitu ketersediaan, kesuburan dan pengelolaan. Status dan kepemilikan lahan. Untuk memberikan dukungan prasarana pendukung seperti infrastruktur perdagangan, energy, dan telekomunikasi. Penyediaan sarana prasarana produksi dan pendukung harus dalam jumlah cukup, berada dekat dengan kawasan pertanian dan biaya peralatan yang terjangkau.

\section{Penguatan Sumber Daya Manusia}

Penguatan Sumber Daya Manusia dilaksanakan dengan pendidikan dan latihan terhadap petugas pendamping (penyuluh, staf teknis, penggerak swadaya masyarakat), petani dan pelaku usaha. Materi pelatihan meliputi: Konsep pengembangan kawasan, penetapan komoditas, penyusunan rancang bangun dan rencana aksi serta aspek teknis usaha tani. Penguatan sumber daya manusia mencakup aspek budidaya, penanganan pasca panen, pengolahan dan pemasaran, serta kelembagaan dalam satu rangkaian yang terfokus pada komoditas unggulan.

\section{Penguatan Kelembagaan}

Penguatan Kelembangaan dalam Kawasan pertanian dilakukan dengan cara pengembangan kelembagaan pembina, kelembagaan pelayanan serta kelembagaan usaha. Kelembagaan pembina meliputi kelembagaan pembina pengembangan sumber daya manusia, serta kelembagaan inovasi dan disiminasi teknologi spesifik lokasi. Kelembagaan pelayanan terdiri dari kelembagaan pelayanan penyediaan sarana produksi, permodalan, dan pemasaran dan informasi pasar. Kelembagaan usaha mencakup kelembagaan usaha kelompok, gabungan usaha ekonomi, koperasi serta kelembagaan usaha kecil, menengah dan besar.

Kerja sama kelembagaan dalam bentuk kerja sama antar pemerintah Daerah, Kemitraan usaha (Public private partnership), bantuan bimbingan teknis serta permodalan dalam kerangka Corporate Social Responsibility (CSR) harus didorong untuk mendukung pengembangan kawasan pertanian yang berbasis klaster.

1. Percepatan adopsi teknologi bioindustri dan bioenargi.

Percepatan Adopsi Teknologi

Percepatan disiminasi teknologi pertanian dilaksanakan dengan mengoptimalkan pemanfaatan teknologi tepat guna dan spesifik lokasi yang dihasilkan oleh lembaga penelitian dan pengembangan serta Perguruan Tinggi. Hasil hasil penelitian dan pengkajian dirakit, dikemas dalam bentuk yang mudah dimengerti, dipahami serta mudah diakses oleh kelompok yang menjadi sasaran. Disiminasi teknologi tidak hanya dilaksanakan dalam bentuk audio visual, leaflet, tetapi lebih diarahkan pada pemahanan di lapang (Sekolah Lapang)

2. Pengembangan industri hilir.

Pengembangan industry hilir di kawasan diarahkan untuk mengolah komoditas pertanian primer menjadi produk olahan baik produk antara (intermediate product) maupun produk akhir (final product), guna peningkatan nilai tambah dan daya saing. Identitas produk suatu kawasan adalah produk akhir suatu kawasan terutama untuk komoditas yang mempunyai prospek di pasar luar negeri.

\section{Pendekatan Teknis Lahan}

Lahan bagian dari bentang alam yang mencakup pengertian fisik termasuk tanah, topografi, dan bahkan keadaan vegetasi alami yang semuannya berpotensi akan berpengaruh secara luas termasuk di pengaruhi oleh berbagai aktivitas flora, fauna dan manusia baik di masa lalu maupun saat ini. Lahan memiliki beberapa fungsi antara lain sebagai

1. Fungsi produksi yaitu sebagai basis bagi sistim penunjang kehidupan yang menyediakan makana, pakan ternak, serat, bahan bakar dan bahan bahan lainnya yang berguna bagi manusia, baik secara langsung ataupun tidak langsung.

2. Fungsi lingkungan biotik, lahan sebagai basisi keragaman daratan (terrestrial) yang menyediakan habitat biologi dan 
plasma nutfah bagi tumbuhan, hewan, dan jasad mikro di atas dan di bawah permukaan tanah.

3. Fungsi pengatur iklim, Lahan dan penggunaannya merupakan sumber (source) dan rosot (sink) gas rumah kaca dan menentukan neraca energy global berupa pantulan, serapan dan transformasi dari energy radiasi matahari dan daur hidrologi.

4. Fungsi hidrologi, Lahan mengatur simpanan dan aliran sumberdaya air tanah dan air permukaan serta kualitasnya.

5. Fungsi Penyimpanan. Lahan sebagai gudang (sumber) berbagai bahan mentah dan mineral untuk dimanfaatkan oleh manusia.

6. Fungsi pengendali sampah dan polusi, dalam hal ini lahan berfungsi sebagai penerima, penyaring, penyangga dan pengubah senyawa senyawa berbahaya.

7. Fungsi Ruang kehidupan. Lahan menyediakan sarana fisik untuk tempat tinggal manusia, industri, dan aktivitas sosial seperti olah raga, dan rekreasi.

8. Fungsi Peninggalan dan penyimpanan. Lahan merupakan media untuk menyimpan dan juga melindungi benda benda bersejarah dan sebagai suatu sumber informasi tentang kondisi iklim dan penggunaan lahan di masa lalu.

9. Fungsi Penghubung Spasial, dalam hal ini lahan menyediakan ruang untuk transportasi manusia, masukan dan produksi serta untuk pemindahan tumbuhan dan binatang antara daerah terpencil dari suatu ekosisitem alami.

Sifat sifat lahan berdasarkan (Masterplan Pengembangan Kawasan Pertanian Provinsi Bengkulu tahun 20172021,2017 ) yaitu atribut atau keadaan unsur unsur lahan yang dapat diukur atau diperkirakan seperti tekstur tanah, struktur tanah, jumlah curah hujan, distribusi hujan, temperature, drainase tanah, dan jenis vegetasi. Sifat lahan merupakan pembeda dari suatu penciri dari segala sesuatu yang terdapat di lahan tersebut dan merupakan pembeda dengan lahan lainnya.

Sifat lahan menunjukkan bagaimana penampilan lahan jika digunakan untuk suatu penggunaan lahan. Sifat lahan akan mempengatuhi keadaan ketersediaan air, peredaran udara, perkembangan akan kepekaan erosi, ketersediaan unsur hara, dan sebagainnya. Perilaku lahan yang menentukan pertumbuhan di sebut dengan kualitas lahan, bagian yaitu:

Sifat sifat lahan terdiri dari beberapa

1. Karakteristik lahan, adalah suatu parameter lahan yang dapat diukur atau diestimasi misalnya kemiringan lereng, curah hujan, tekstur tanah dan struktur tanah. Satuan parameter lahan dalam survey sumberdaya lahan pada umumnya disertai deskripsi karakteristik lahan.

2. Kualitas lahan, mempengaruhi tingkat kesesuaian lahan untuk penggunaan tertentu. Kualitas lahan dinilai atas dasat karakteristik lahan yang berpengaruh pada suatu kualitas lahan tertentu, tetapi tidak dapat berpengaruh pada kualitas lahan lainnya.

3. Pembatas lahan, merupakan factor pembatas yang tidak atau hamper tidak dapat memenuhi persyaratan untuk memperoleh produksi yang optimal dan pengelolaan dari suatu penggunaan lahan tertentu. Pembatas lahan dapat dibedakan menjadi dua, yaitu (1) pembatas lahan permanen, pembatas lahan yang tidak dapat diperbaiki dengan usaha usaha perbaikan lahan (band improvement). (2) pembatas lahan sementara, pembatas lahan yang dapat diperbaiki dengan cara pengelolaan lahan.

4. Pesyaratan penggunaan lahan. Pesyaratan penggunaan lahan dapat dikelompokkan menjadi beberapa bagian yaitu:

a. Persyaratan ekologikal, contohnya ketersedian air, ketersediaan unsur hara, ketersedian oksigen, resiko banjir, lingkup temperature, kelembapan udara dan periode kering.

b. Persyaratan pengelolaan, contohnya persiapan pembibitan dan mekanisasi selama panen.

c. Persyaratan konservasi, contohnya control erosi, resioko komplen tanah, resiko pembentukan kulit tanah.

d. Persyaratan perbaikan, contohnya pengeringan lahan, tanggap terhadap pemupukan.

5. Perbaikan lahan adalah aktivitas yang dilakukan untuk memperbaiki kualitas lahan pada sebidang lahan untuk mendapatkan keuntungan dalam meningkatkan produksi pertanian. Perbaikan lahan mutlak dilakukan agar kualitas lahan dapat terus terjaga dan 
bermanfaat bagi generasi yang akan dating.

\section{Penggunaan Lahan}

Pemanfaatan lahan untuk membantu kebutuhan hidup manusia maka butuh pengelolaan. Untuk itu di perlukan kebijakan atau keputusan untuk penggunaan lahan lebih lanjut. Penggunaan lahan adalah suatu bentuk usaha manusia dalam pemanfaatan lahan untuk kebutuhan hidup . Lahan bisa di gunakan untuk kegiatan pertanian ataupun non pertanian. Penggunaan lahan dibidang pertanian seperti untuk kebun, sawah, lahan peternakan dan lainnya, untuk non pertanian seperti untuk pemukiman, industri dan lainnya.

Penggunaan lahan yang tidak sesuai dengan kemampuan lahan akan mengakibatkan berkurangnya kemampuan lahan dalam memproduksi hasil pertanian dan menimbulkan lahan kritis. Lahan yang kritis mengalami kerusakan baik secara fisis kimia maupun biologisnya dan membahayakan fungsi hidrologisnya, produksi pertanian, pemukiman dan kondisi sosial ekonominya.

Kopi yang ada di Kabupaten Rejang Lebong adalah jenis Kopi Robusta. Jenis Kopi Robusta ini dapat hidup pada ketinggian 500$1000 \mathrm{dpl}$, dengan suhu $20^{\circ} \mathrm{C}$. Curah hujan yang di butuhkan dalam 1 tahun minimal 1000-2000 mm. Kopi Robusta cocok dengan musim kemarau 3-4 bulan tetapi harus sering ada hujan yang cukup.

\section{Curah Hujan}

Curah hujan merupakan ketinggian air hujan yang terkumpul dalam tempat yang datar, tidak menguap, tidak meresap dan tidak mengalir. Curah hujan 1 millimeter artinya dalam luasan satu meter persegi pada tempat yang datar tertampung air setinggi satu millimeter atau tertampung air sebanyak satu liter. Intensitas hujan adalah banyaknya curah hujan pesatuan jangka waktu tertentu. Apabila dikatakan intensitasnya besar berartu hujan lebat dan kondisi ini sangat berbahaya karena berdampak banjir, longsor dan kerusakan lainnya terhadap tanaman.

Hujan berperan penting dalam siklus hidrologi. Lembaban dari air laut menguap berubah menjadi awan, terkumpul menjadi awan mendung, lalu turun kebumi, dan kembali kelaut melalui sungai dan anak sungai untuk mengulangi daur ulang semula.
Intensitas curah hujan adalah jumlah curah hujan yang dinyatakan dalam tinggi hujan atau volume hujan tiap satuan waktu, yang terjadi pada satu kurun waktu air hujan terkonsentrasi. Biasanya intensitas curah hujan berbeda beda terngantung dengan lamanya curha hujan dan frekuensi hujan terjadinya.

\section{Kondisi Iklim}

Iklim merupakan salah satu factor determinan yang sangat menentukan tingkat kesesuaian lahan, produktivitas, jenis dan mutu produk. Setiap jenis tanaman memerlukan unsur iklim dengan kisaran tertentu dalam setiap fase pertumbuhannya. Pada keadaan tertentu fluktuasi unsur iklim yang ekstrim menjadi factor pembatas terutama pada fase kritis yang pengaruhnya sangat besar terhadap penurunan hasil tanaman. Tetapi di sisi lain, keragaman dan dinamika iklim dapat bermanfaat bagi pengembangan sistim dan usaha agribisnis, terutama kaitannya dengan jenis dan mutu hasil serta periode panen.

\section{Kesesuaian Iklim Tanaman Kopi}

Pengembangan kawasan perkebunan kopi untuk suatu wilayah tertentu penting untuk memperhatikan kesesuaian iklim tanaman, karena ini akan berkaitan dengan proses fotosintesis tanaman yang akan berpengaruh terhadap hasil produksi tanaman (Wintgens NJ, 2012)

\section{Dampak Perubahan Iklim terhadap produksi Tanaman Kopi}

Dampak perubahan iklim yang mungkin terjadi pada produksi kopi ((Baker PS. Haggar J, 2007) adalah:

1. Kualitas, Perubahan iklim akan berpengaruh pada kualitas kopi yang dihasilkan, iklim yang panas menyebabkan kopi berbunga lebih cepat tetapi kualitasnya berkurang.

2. Kuantitas, Peningkatan suhu yang terjadi berpengaruh terhadap metabolisme tanaman kopi seperti berbunga, fotosintesis, yang dapat menurukan hasil produksi tanaman kopi. 
3. Hama dan Penyakit, Peningkatan suhu akan mendukung perkembangan hama dan penyakit tertentu yang merusak tanaman kopi.

4. Hasil Produksi Global. Perubahan lingkungan memungkinkan wilayah yang cocok untuk perkebunan kopi menjadi berkurang. Hal ini menyebakan produksi global cenderung memiliki fluktuasi yang tinggi. Beberapa gangguan yang sangat hebat pada hasil salah satu produsen utama akan berpengaruh pada produksi global.

\section{SIMPULAN}

Penting dalam perencanaan pengembangan kawasan Kopi di Kabupaten Rejang Lebong untuk memperhatikan kondisi lahan, cuaca dan iklim di kawasan yang akan di kembangkan agar dapat menghasilkan produksi yang optimal

\section{DAFTAR PUSTAKA}

Baker PS. Haggar J. (2007). The Impact on Global Coffee. Los Angeles(US): Specialty Coffee Association of America.

BAPPENAS. (2004). Tata Cara Perencanaan Pengembangan Kawasan untuk percepatan Pembangunan Daerah (1 ed.). Jakarta: Direktorat Pengembangan Kawasan Khusus dan Tertinggal.

Ernan Rustiadi. Sunsun Saefulhakim. Dyan R. (2009). Perencanaan dan pengembangan wilayah (ke 4 Mei 2; A. E. Pravitasari, ed.). Jakarta: Yayasan Pustaka Obor Indonesia.

Endang Sri Sudalmi. (2010). Pembangunan Pertanian Berkelanjutan. Junal Inovasi Pertanian, 9(2), 15-28

Fachrudin, Hilman Tamiami dan Muhammad Dolok Lubis (2016). Planning for Riverside Area as Water Tourism Destination to Improve Quality of Life Local Residents, Case Study: Batuan - Sikambing River, Medan, Indonesia. Jurnal Social and Behavioral Sciences 234 ( 434 - 441_

Harun, U. (2010). Model Perencanaan Pengembangan Wilayah Kepulauan
Nusa Tenggara. Jurnal Perencanaan Wilayah dan Kota, 10(1), 1-14.

Kunarjo. (2002). Perencanaan dan Pengendalian Program

Pembangunan. Jakarta: Universitas Indonesia Press. Jakarta.

Masterplan Pengembangan Kawasan Pertanian Provinsi Bengkulu tahun 2017-2021. (2017). Rejang Lebong.

Setiyanto, A. (2013). Approach and Implementation of Priority Agricultural Commodity Zone Development. Forum Penelitian Agro Ekonomi, 31 No 2(Tanaman Pangan), 171-195.

Spatio temporal analysis trend of land use and land cover change against temperature based on remote sensing data in Malang City. 2016. Procedia Social and Behavioral Sciences 227 ( 2016 ) $232-238$

Sri Sudalmi, E. (2010). Pembangunan Pertanian Berkelanjutan. Inovasi, 9(2), 15-27.

Susanto, A. (2016). Perencanaan Pengelolaan Kawasan Konservasi Berbasis Pemberdayaan Masyarakat (Studi Pada Balai Taman Nasional Gunung Merapi Provinsi Daerah Istimewa Yogyakarta). Jurnal Ilmiah Administrasi Publik (JIAP).

Syafa'at, N., Simatupang, P., Marianto, S., \& Pranadji, T. (2016). Konsep Pengembangan Wilayah Berbasis Agribisnis Dalam Rangka Pemberdayaan Petani. Forum penelitian Agro Ekonomi. https://doi.org/10.21082/fae.v21n1.20 03.26-43

Tarigan, R. (2016). Perencanaan Pembangunan Wilayah. Jakarta: PT. Bumi Aksara.

Todaro. (2000). Pembangunan Ekonomi di Dunia Ketiga (D. H. M. . Munandar, ed.). Jakarta: Erlangga.

Wintgens NJ. (2012). Coffee: Growing, Processing, Sustainable Production. A Guidebook for Growers, Processors, Traders, and Researchers. Weinhem(GE): Wiley- 
$\mathrm{VCH}$.

Purwanto, et al. Spatio temporal analysis trend of land use and land cover change against temperature based on remote sensing data in Malang City. 2016. Procedia - Social and Behavioral Sciences 227 ( 2016 ) $232-238$ 